\title{
New Potential Adjuncts to Treatment of Children With Type 1 Diabetes Mellitus
}

\author{
VANDANA S. RAMAN AND RUBINA A. HEPTULLA \\ Department of Pediatrics, Division of Pediatric Endocrinology, Baylor College of Medicine, Houston, TX 77030
}

\begin{abstract}
Insulin administration is the primary therapy for type 1 diabetes mellitus (T1DM). Current available insulin therapies do not successfully enable children with T1DM to reach glycemic goals without side effects such as hypoglycemia and weight gain. Pramlintide is a synthetic analog of human amylin that acts in conjunction with insulin to delay gastric emptying and inhibit the release of glucagon and is indicated for use in patients with type 1 and type 2 diabetes. Recent studies in adult patients have examined the role of glucagon-like peptide 1 (GLP-1) and agents that bind to its receptor in type 1 diabetes. It is hypothesized that a major component of the glycemic effect is attributable to the known action of GLP-1 to delay gastric emptying and to inhibit glucagon secretion. Further studies with the use of amylin analogs and long-acting GLP-1 agonists as congeners with insulin in T1DM are indicated in children. In recent years, our better understanding of the pathophysiology of diabetes has led to the development of new therapies for diabetes. This article reviews the potential use of these newer pharmacologic agents as adjunctive therapy in T1DM in children and adolescents. (Pediatr Res 65: 370-374, 2009)
\end{abstract}

$\mathrm{T}^{\mathrm{s}}$ ype 1 diabetes mellitus (T1DM) is an autoimmune process with a strong genetic component causing destruction and dysfunction of the pancreatic $\beta$-cells. It involves both insulin and amylin deficiencies. Insulin administration is the primary therapy for T1DM.

Current standards of care recommend intensive diabetes management and lowering hemoglobin $\mathrm{A} 1 \mathrm{c}(\mathrm{HbA} 1 \mathrm{c})$ to as close to normal as possible. However, 87 years after the discovery of insulin, physicians and patients still struggle for optimal diabetes control because of limitations of insulin therapy.

The Diabetes Control and Complication Trial demonstrated the direct relationship between glycemic control as predicted by $\mathrm{HbA} 1 \mathrm{c}$ and onset and prevention of microvascular complications $(1,2)$. Studies show a strong correlation between $\mathrm{HbA1c}$ and plasma glucose levels both at fasting and over postprandial periods $(3,4)$. Studies also suggest that postprandial hyperglycemia is an important risk factor for the development of macrovascular disease $(5,6)$. Increased glycemic variability seems to correspond with elevated markers of oxidative stress and inflammation associated with cardiovas-

Received June 30, 2008; accepted October 15, 2008.

Correspondence: Rubina A. Heptulla, M.D., Clinical Care Center, Suite 1020, 6621

Fannin Street CC 1020.05, Houston, TX 77030-2399; e-mail: heptulla@bcm.tmc.edu

Supported by NIH grant DK065059 and R01DK077166-01 to RAH. cular disease (7). Thus, reductions in postprandial glycemic variability may be an important step in lowering complications related to diabetes (8). However, as insulin doses are pushed in an attempt to normalize blood glucose after meals, risk of hypoglycemia and excessive weight gain occur.

This failure to achieve and maintain euglycemia in majority of children with T1DM provides an impetus to seek newer adjunctive therapies that are both safe and effective. In recent years, our better understanding of the pathophysiology of diabetes has led to the development of new therapies for diabetes. This article reviews the potential use of newer pharmacologic agents as adjunctive therapy in T1DM in children.

Pathophysiology of type 1 diabetes and rationale for adjunctive therapy. The postprandial glucose profile is determined by several factors: the rate and extent of glucose absorption, secretory patterns of various hormones (insulin, glucagon, amylin, and incretin hormones), and their effects on hepatic and peripheral tissue glucose metabolism. Studies have shown that the postmeal responses of insulin, glucagon, and glucose differ between individuals with and without diabetes. Typically in a person without diabetes, the blood glucoses are tightly controlled (9). Postprandially, the concurrent increases in blood glucose and insulin results in suppression of hepatic glucose production by suppressing glycogenolysis and gluconeogenesis and increase in glucose uptake and utilization by the peripheral tissues particularly muscle and fat. In those with diabetes, insulin release is deficient, paradoxical rise in glucagon contributes to postprandial hyperglycemia (10).

Role of gastric emptying. Gastric-emptying rate is an important determinant of postprandial blood glucose. The rate of gastric emptying has a direct effect on the rate of glucose appearance after a meal as a result of absorption of glucose and simple carbohydrates from the proximal small intestine (11). Postprandial glucose can be as much as $34 \%$ higher in normal healthy subjects who empty their stomachs rapidly than in those who have a slower gastric emptying rate (12). Gastric emptying in patients with diabetes is an area of much controversy. There are studies that suggest that there is accelerated, normal, and delayed gastric emptying in T1DM (13-
Abbreviations: GLP-1, Glucagon-like peptide-1; GLP-1R, Glucagon-like peptide-1 Receptor; HbA1c, Hemoglobin A1c; pdx1, Pancreatic duodenal homeobox 1; T1DM, Type 1 diabetes mellitus; T2DM, Type 2 diabetes mellitus 
Table 1. Mechanism for adjunctive therapy in TIDM

\begin{tabular}{ccc}
\hline Class of drug & Drug & Main mechanism of action \\
\hline $\begin{array}{c}\text { Synthetic amylin } \\
\text { analogs }\end{array}$ & Pramlintide & $\begin{array}{c}\text { Delayed gastric emptying, } \\
\text { glucagon suppression }\end{array}$ \\
$\begin{array}{c}\text { GLP-1 receptor } \\
\text { agonists }\end{array}$ & Exenatide & $\begin{array}{c}\text { Delayed gastric emptying, } \\
\text { glucagon suppression, } \\
\end{array}$ \\
& & ( \pm enhancement of \\
& insulin secretion) \\
\hline
\end{tabular}

15). In T1DM patients and healthy subjects, acute hyperglycemia slows gastric emptying of both solids and nutrient liquids, when compared with euglycemia $(16,17)$. Patients with known autonomic neuropathy and longstanding diabetes have gastroparesis (18).

Rationale for adjunctive therapy. Glucose homeostasis is dependent on the complex interplay of multiple hormones: insulin, glucagon, amylin, and gastrointestinal peptides, including glucagon-like peptide-1 (GLP-1) and gastric inhibitory peptide. By the addition of adjunctive therapies, glucose homeostasis may be achieved by a more balanced approach (19). The mechanism of action for adjunctive therapies in T1DM is summarized in Table 1.

\section{REPLACEMENT OF AMYLIN AS PHYSIOLOGIC APPROACH TO THE TREATMENT OF DIABETES}

Amylin physiology and pathophysiology. In 1987, it was reported that pancreatic beta cells secrete another hormone, which was identified as amylin (20). In type 1 diabetes, owing to the destruction of the $\beta$-cells, patients have an absolute deficiency of both insulin and amylin. Amylin and insulin have complementary actions in regulating glucose homeostasis. Amylin has glucose lowering effects by (1) suppression of endogenous glucagon production, especially in the postprandial state; (2) slowing of gastric emptying time; and (3) reduction of postprandial hepatic glucose production. It also causes centrally mediated induction of satiety.

Effects on gastric emptying. Amylin seems to normalize gastric motility and gastric-emptying time (19,21). Amylin thus regulates delivery of nutrients to the small intestine and the rate of glucose appearance in the blood.

Pramlintide: synthetic analog of amylin. Pramlintide is a synthetic analog of human amylin. In 2005, pramlintide was approved by the Food and Drug administration for use in patients with diabetes treated with mealtime insulin who have not achieved glycemic goals. Pramlintide reduces postprandial glycemia and glucose fluctuations, resulting in improved glycemic control without associated weight gain (22).

Native amylin is glue like and unstable as a compound solution and has a propensity to aggregate and adhere to the surfaces. Pramlintide has similar physiologic effects as native amylin. Pramlintide is a peptide and is therefore administered systemically, e.g. via s.c. injection. It does not impede the glucagon response to hypoglycemia or attenuate the effects of counterregulatory hormones triggered by hypoglycemia (catecholamines, growth hormone, cortisol, and glucagon) (23).

Clinical studies in type 1 diabetes. Short-term clinical studies in patients with T1DM showed that mealtime amylin replacement with pramlintide slows the rate of nutrient delivery from the stomach to the small intestine $(24,25)$ and prevents an abnormal increase in glucagon after meals $(26,27)$. All of these effects were achieved with pramlintide doses of 30 or $60 \mu \mathrm{g}$, which resulted in plasma pramlintide concentrations similar to the postprandial amylin levels seen in healthy subjects. In our experience in adolescents with T1DM, increasing the insulin dose by $60 \%$ before a meal did not correct immediate postprandial hyperglycemia. Pramlintide was effective in decreasing immediate postprandial hyperglycemia in adolescents with T1DM $(28,29)$. We have also found that postprandial hyperglycemia is considerably reduced in adolescents with T1DM when treated with premeal $30 \mu \mathrm{g}$ pramlintide and postmeal insulin, without significant side effects (unpublished data).

Long-term clinical studies in adults with T1DM show that adjunctive therapy with pramlintide facilitates further improvement of overall glycemic control without the increase in body weight and/or severe hypoglycemia (30-32). In a multicenter study of 480 T1DM patients (16-70 y of age), Whitehouse et al. (30) showed that treatment with pramlintide led to a mean reduction in $\mathrm{HbA1c}$ of $0.67 \%$ from baseline to week 13 that was significantly greater than the reduction with placebo $(0.16 \%)$; a significant treatment difference was sustained through week 52. Ratner et al. (31) showed that the addition of pramlintide $60 \mu \mathrm{g}$ three times or four times daily to insulin led to significant reductions in $\mathrm{HbA1c}$ of $0.29 \%$ and $0.34 \%$, respectively, compared with a $0.04 \%$ reduction in placebo group, over 52 wk.

Effects on weight. Several studies have assessed the effect of pramlintide on weight control in adults with T1DM. Ratner et al. (31) reported a significant reduction in body weight from baseline to week 52 of $0.4 \mathrm{~kg}$ in the pramlintide treatment groups, compared with a $0.8-\mathrm{kg}$ gain in body weight in the placebo group. A 29-wk study by Edelman et al. (32) of 296 patients with T1DM showed that pramlintide treatment significantly reduced weight (pramlintide $-1.3 \pm 0.30$, placebo $+1.2 \pm 0.30 \mathrm{~kg}$ ), despite equivalent $\mathrm{HbA} 1 \mathrm{c}$ reductions relative to placebo.

The mechanism underlying the observed weight reduction with pramlintide is not fully understood. The effects seem to be centrally mediated. High-density amylin sites are identified in the dorsal raphe and nucleus acumbens, the regions in brain that control feeding behavior. Pramlintide's effect on appetite targets peripheral episodic satiety signals (33). In rodents, amylin dose dependently reduced food intake and body weight by affecting the size and duration of meals $(34,35)$. In a randomized, double blind, placebo-controlled crossover study, preprandial injection of pramlintide elicited a $20 \%$ reduction in ad libitum food intake in insulin-treated patients with T2DM (36). In another study, low-dose pramlintide reduced food intake and meal duration in healthy, normal-weight subjects (37).

Other effects. Pramlintide reduced postprandial markers of oxidative stress, including nitrotyrosine and oxidized LDL that are associated with increased risk of cardiovascular disease and diabetic microvascular complications in a study (38).

Adverse effects and practical considerations. The most common adverse effects include nausea, vomiting, and an- 
orexia. Rates of nausea in studies have ranged from 9.5 to $59 \%$ with most cases being mild to moderate in nature and resolving in 2-8 weeks. Pramlintide in itself does not cause hypoglycemia. When coadministered with insulin, it increases the risk of insulin-induced hypoglycemia. Insulin doses may need to be reduced by $20-50 \%$. Pramlintide should be avoided in patients with gastroparesis because it slows gastric emptying. Currently, weight-based pramlintide dosing information is unavailable. In adults with T1DM, pramlintide is usually initiated at a dose of $15 \mu \mathrm{g}$ and titrated in $15-\mu \mathrm{g}$ increments to a final dose of $60 \mu \mathrm{g}$ based on tolerability to nausea. If the $45-\mu \mathrm{g}$ and $60-\mu \mathrm{g}$ doses are not well tolerated, a maintenance dose of $15-30 \mu \mathrm{g}$ can be used. Pramlintide is taken by s.c. injection just before mealtimes and should be administered in a separate syringe at an injection site distinct from that of concurrent insulin. Pramlintide is yet to be approved for use in children. In general, candidates for treatment include patients who have failed to achieve glycemic control despite individualized insulin management, and who are able to monitor blood glucose frequently and are under the care of healthcare professional skilled in the use of insulin.

In conclusion, amylin replacement with pramlintide as an adjunct to insulin therapy potentially represents a novel and more physiologic approach toward improved metabolic control in children with T1DM. However, more short-term and long-term studies with pramlintide are needed in the pediatric population.

\section{DIABETES AND THE INCRETIN EFFECT}

The incretin effect was first described after the observation that insulin responses to oral glucose exceeded those measured after administration of equivalent amount of i.v. glucose. In healthy individuals, incretin effect is responsible for $50-70 \%$ of insulin response to oral glucose (39). Most postprandial hormones have incretin-like effects; the two predominant incretin hormones are gastric inhibitory peptide and GLP-1. GLP-1 seems to be responsible for most of incretin effect on pancreatic beta-cell function.

Physiology of GLP-1. GLP-1 is released from intestinal L-cell, which is the major source, with small quantities released from pancreatic alpha cells. It exerts its actions through a specific $G$ protein-coupled receptor expressed on islet $\beta$-cells (40). GLP-1 receptors (GLP-1R) are found in many tissues, including pancreatic islets, stomach, small intestine, kidney, lung, brain, and pituitary gland. It is a potent suppressor of glucagon in vivo. The insulinotropic action of GLP-1 is glucose dependent. It also stimulates insulin synthesis through enhancing proinsulin gene transcription (41). The biologic half-life of GLP-1 is very short, about 2 min, because of enzymatic degradation by dipeptidyl peptidase-IV and renal clearance (42). It inhibits both gastric acid secretion and gastric emptying after meals via vagal afferent central mechanisms $(43,44)$ and contributes to reducing postprandial glycemic excursions (44).

GLP-1 in diabetes. Studies have suggested that endogenous secretion of GLP-1 is defective in T2DM (45). The existing literature about GLP-1 in T1DM produces conflicting results.
A study has reported a lack of GLP-1 secretion in patients with T1DM in response to a meal (46). Another study has reported normal GLP-1 response to meal among patients with T1DM compared with healthy subjects (47). However, fasting GLP-1 levels were lowest in patients with T1DM. In one pediatric study, decreasing $\beta$-cell function during the first year of T1DM was associated with increasing postprandial blood glucose, glucagon, and GLP-1 (48).

Effect on glycemic excursions after meals in T1DM. Several small, short-term studies in adults suggest that GLP-1 may have the potential for therapeutic use in T1DM (49). Continuous i.v. infusion of GLP-1 without insulin in patients with T1DM who had detectable insulin responses to meals, prevented a rise in blood glucose levels after ingestion of a meal after overnight fasting (50). This was accompanied by suppression of the abnormal glucagon response to the meal. There is potential for s.c. GLP-1 to improve short-term glycemic control in patients with T1DM when administered before meals in addition to insulin. In a study of patients with T1DM and absent residual insulin secretion, postprandial blood glucose levels were significantly reduced with GLP-1 in a 5-d study period without an increase in significant hypoglycemia or a change in dose of insulin (51). In another study in patients with T1DM, where three patients had residual insulin secreting capacity, GLP-1 when compared with placebo reduced glucagon levels by $50 \%$ and increased C-peptide levels to a small but significant degree (52).

GLP-1 and pancreas. In addition to these glucoregulatory effects, GLP-1 may be important in beta-cell proliferation and survival, making it an attractive candidate for assessment in prolongation of beta cell survival (53). In animal studies, GLP-1 is associated with induction of pancreatic duodenal homeobox $1(p d x 1)$ gene expression (54,55). $P d x 1$ is a transcription factor, which is primarily expressed in the endocrine pancreas and subsets of enteroendocrine cells in the duodenum and is critical for pancreatic development and formation (55). GLP-1 actions may be mediated through $p d x 1$, and thus influence beta-cell proliferation and survival (56). Furthermore, GLP-1 regulates a subset of genes, including proinsulin, GLUT-2, and glucokinase that are known transcriptional targets of $p d x l$ action (57). Apoptosis-related cell death is a feature of both type 1 and type 2 diabetes mellitus. GLP-1 has antiapoptotic properties independent of its action on glucose regulation and islet proliferation. In mice with streptozotocininduced diabetes, which causes apoptosis, treatment with exendin-4, a GLP-1 receptor analog, resulted in euglycemia significantly longer than those that were not treated with GLP-1 (58). The increase in $\beta$-cell mass observed after treatment with GLP-1R agonists is thought to arise from direct stimulation of $\beta$-cell proliferation, and via enhancement of islet neogenesis (59). More recent evidence suggests that GLP- 1 also preserves $\beta$-cell mass via inhibition of apoptosis (60). These parameters are difficult to assess in human subjects. There is evidence that experimentally induced changes in $\beta$-cell mass of nonobese diabetic mice early in the course of the autoimmune process can inhibit the subsequent development of disease (61). As T1DM is thought to result from progressive $\beta$-cell destruction and failure to regenerate $\beta$-cell 
mass, it remains possible that intervention with GLP-1R agonists will modify the natural course of $\beta$-cell destruction and/or regeneration, resulting in clinically detectable improvements in insulin secretion and glucose control.

Exenatide. Exenatide is a synthetic version of exendin-4, a naturally occurring 39-amino acid peptide originally isolated from the salivary secretions of the lizard Heloderma suspectum. It is a partial structural analog of human GLP-1, sharing $53 \%$ amino acid sequence homology. It binds to and activates human GLP-1 receptor. It is not a substrate for dipeptidyl peptidase-IV and has a much longer half-life than GLP-1.

Clinical studies of exenatide in T1DM. Exendin-4 administration before a meal in adults with T1DM resulted in a significant reduction in postprandial blood glucose values which were comparable with those of healthy control subjects. Plasma glucagon concentrations were abnormally high compared with those of control subjects with insulin alone, but the concentrations were reduced and did not differ from control subjects after exendin-4 was added. Antihyperglycemic effects of the drug were attributed to suppressed glucagon secretion and delayed gastric emptying rather than insulinotropic effect. Only one patient had significant hypoglycemia during the single-dose study (62).

The literature regarding appropriate insulin adjustment in patients with T1DM who are using exenatide is inconclusive. Researchers have administered GLP-1 for $5 \mathrm{~d}$ to patients with T1DM without any reduction in their insulin dosage and a single episode of mild hypoglycemia was observed in one patient of 23 subjects. A single dose study showed that $50 \%$ reduction in meal-related insulin requirement was associated with infusion of GLP-1 (63).

Adverse effects and practical considerations. Nausea is the most common side effect and is dose dependent, can occur in $30-50 \%$ of patients as seen in adults with type 2 diabetes mellitus, although is usually transient. There is a risk of mild to moderate hypoglycemia when exenatide is used with a sulfonylurea in T2DM. Exenatide results in a moderate reduction in weight, which does not seem to be related to the adverse gastrointestinal effects. Exenatide has resulted in low levels of antiexenatide antibodies in approximately $40 \%$ of patients but had no effect on glucose control. About $6 \%$ of patients developed high antibody levels, which could result in a diminished response (64). Postmarketing cases of acute pancreatitis are reported in patients treated with exenatide including six cases of hemorrhagic and necrotizing pancreatitis. All patients required hospitalization and two deaths were reported (www.fda.gov). Exenatide and other potentially suspect drugs should be promptly discontinued and not restarted if pancreatitis is suspected. Exenatide is approved for use in adults with T2DM in conjunction with metformin or oral hypoglycemic agents. Exenatide is not approved by the Food and Drug administration approved for treatment of T1DM or use with insulin. There are no studies with use of exenatide in children. Currently, studies are underway examining the role of exenatide in T1DM in children and adults.

In conclusion, insulin replacement therapy remains the corner stone of diabetes management for patients with T1DM. Despite islet transplantation and advances in the delivery and pharmacology of insulin, such as the development of continuous s.c. insulin infusion and rapid- and long-acting insulin analogs, many children with T1DM still fail to achieve glycemic targets. The limitations of insulin therapy with hypoglycemia and inadvertent weight gain become increasingly evident as patients approach glycemic targets.

The search for adjunctive agents in treatment of T1DM is stimulated by ongoing difficulties in safely achieving the target necessary to prevent metabolic complications in T1DM. More studies are needed to establish safety and efficacy of the above therapies in the pediatric population.

\section{REFERENCES}

1. 1995 The relationship of glycemic exposure (HbA1c) to the risk of development and progression of retinopathy in the diabetes control and complications trial. Diabetes 44:968-983

2. Lachin JM, Genuth S, Nathan DM, Zinman B, Rutledge BN 2008 Effect of glycemic exposure on the risk of microvascular complications in the diabetes control and complications trial—revisited. Diabetes 57:995-1001

3. Avignon A, Radauceanu A, Monnier L 1997 Nonfasting plasma glucose is a better marker of diabetic control than fasting plasma glucose in type 2 diabetes. Diabetes Care 20:1822-1826

4. El-Kebbi IM, Ziemer DC, Cook CB, Gallina DL, Barnes CS, Phillips LS 2004 Utility of casual postprandial glucose levels in type 2 diabetes management. Diabetes Care 27:335-339

5. Hanefeld M, Koehler C, Schaper F, Fuecker K, Henkel E, Temelkova-Kurktschiev T 1999 Postprandial plasma glucose is an independent risk factor for increased carotid intima-media thickness in non-diabetic individuals. Atherosclerosis 144:229-235

6. Temelkova-Kurktschiev TS, Koehler C, Henkel E, Leonhardt W, Fuecker K, Hanefeld M 2000 Postchallenge plasma glucose and glycemic spikes are more strongly associated with atherosclerosis than fasting glucose or HbAlc level. Diabetes Care 23:1830-1834

7. Quagliaro L, Piconi L, Assaloni R, Martinelli L, Motz E, Ceriello A 2003 Intermittent high glucose enhances apoptosis related to oxidative stress in human umbilical vein endothelial cells: the role of protein kinase $\mathrm{C}$ and $\mathrm{NAD}(\mathrm{P}) \mathrm{H}$-oxidase activation. Diabetes 52:2795-2804

8. Monnier L, Colette C 2008 Glycemic variability: should we and can we prevent it? Diabetes Care 31:S150-S154

9. Unger RH 1971 Glucagon physiology and pathophysiology. N Engl J Med 285:443449

10. Muller WA, Faloona GR, Aguilar-Parada E, Unger RH 1970 Abnormal alpha-cell function in diabetes. Response to carbohydrate and protein ingestion. N Engl J Med 283:109-115

11. Dinneen S, Gerich J, Rizza R 1992 Carbohydrate metabolism in non-insulindependent diabetes mellitus. N Engl J Med 327:707-713

12. Horowitz M, Edelbroek MA, Wishart JM, Straathof JW 1993 Relationship between oral glucose tolerance and gastric emptying in normal healthy subjects. Diabetologia 36:857-862

13. Linke R, Muenzing W, Tatsch K 2005 Is normal gastric emptying a predictor of normal gastric function? Nuklearmedizin 44:81-85

14. Lipp RW, Schnedl WJ, Hammer HF, Kotanko P, Leb G, Krejs GJ 1997 Evidence of accelerated gastric emptying in longstanding diabetic patients after ingestion of a semisolid meal. J Nucl Med 38:814-818

15. Meier M, Linke R, Tatsch K, Standl E, Schnell O 2002 An advanced approach for the assessment of gastric motor function in long-term type 1 diabetes mellitus with and without autonomic neuropathy. Clin Auton Res 12:197-202

16. Oster-Jorgensen E, Pedersen SA, Larsen ML 1990 The influence of induced hyperglycaemia on gastric emptying rate in healthy humans. Scand J Clin Lab Invest 50:831-836

17. Fraser RJ, Horowitz M, Maddox AF, Harding PE, Chatterton BE, Dent J 1990 Hyperglycaemia slows gastric emptying in type 1 (insulin-dependent) diabetes mellitus. Diabetologia 33:675-680

18. Samsom M, Roelofs JM, Akkermans LM, van Berge Henegouwen GP, Smout AJ 1998 Proximal gastric motor activity in response to a liquid meal in type I diabetes mellitus with autonomic neuropathy. Dig Dis Sci 43:491-496

19. Edelman SV, Caballero L 2006 Amylin replacement therapy in patients with type 1 diabetes. Diabetes Educ 32:119S-127S

20. Cooper GJ, Willis AC, Clark A, Turner RC, Sim RB, Reid KB 1987 Purification and characterization of a peptide from amyloid-rich pancreases of type 2 diabetic patients. Proc Natl Acad Sci USA 84:8628-8632

21. Young AA, Gedulin B, Vine W, Percy A, Rink TJ 1995 Gastric emptying is accelerated in diabetic BB rats and is slowed by subcutaneous injections of amylin. Diabetologia 38:642-648

22. Want L 2006 Use of pramlintide: the patient's perspective. Diabetes Educ 32:111S$118 \mathrm{~S}$

23. Amiel SA, Heller SR, Macdonald IA, Schwartz SL, Klaff LJ, Ruggles JA, Weyer C, Kolterman OG, Maggs DG 2005 The effect of pramlintide on hormonal, metabolic 
or symptomatic responses to insulin-induced hypoglycaemia in patients with type 1 diabetes. Diabetes Obes Metab 7:504-516

24. Samsom M, Szarka LA, Camilleri M, Vella A, Zinsmeister AR, Rizza RA 2000 Pramlintide, an amylin analog, selectively delays gastric emptying: potential role of vagal inhibition. Am J Physiol Gastrointest Liver Physiol 278:G946-G951

25. Kong MF, Stubbs TA, King P, Macdonald IA, Lambourne JE, Blackshaw PE, Perkins AC, Tattersall RB 1998 The effect of single doses of pramlintide on gastric emptying of two meals in men with IDDM. Diabetologia 41:577-583

26. Nyholm B, Orskov L, Hove KY, Gravholt CH, Moller N, Alberti KG, Moyses C, Kolterman O, Schmitz O 1999 The amylin analog pramlintide improves glycemic control and reduces postprandial glucagon concentrations in patients with type 1 diabetes mellitus. Metabolism 48:935-941

27. Fineman MS, Koda JE, Shen LZ, Strobel SA, Maggs DG, Weyer C, Kolterman OG 2002 The human amylin analog, pramlintide, corrects postprandial hyperglucagonemia in patients with type 1 diabetes. Metabolism 51:636-641

28. Rodriguez LM, Mason KJ, Haymond MW, Heptulla RA 2007 The role of prandial pramlintide in the treatment of adolescents with type 1 diabetes. Pediatr Res 62:746-749

29. Heptulla RA, Rodriguez LM, Bomgaars L, Haymond MW 2005 The role of amylin and glucagon in the dampening of glycemic excursions in children with type 1 diabetes. Diabetes 54:1100-1107

30. Whitehouse F, Kruger DF, Fineman M, Shen L, Ruggles JA, Maggs DG, Weyer C, Kolterman OG 2002 A randomized study and open-label extension evaluating the long-term efficacy of pramlintide as an adjunct to insulin therapy in type 1 diabetes. Diabetes Care 25:724-730

31. Ratner RE, Dickey R, Fineman M, Maggs DG, Shen L, Strobel SA, Weyer C, Kolterman OG 2004 Amylin replacement with pramlintide as an adjunct to insulin therapy improves long-term glycaemic and weight control in Type 1 diabetes mellitus: a 1-year, randomized controlled trial. Diabet Med 21:1204-1212

32. Edelman S, Garg S, Frias J, Maggs D, Wang Y, Zhang B, Strobel S, Lutz K, Kolterman O 2006 A double-blind, placebo-controlled trial assessing pramlintide treatment in the setting of intensive insulin therapy in type 1 diabetes. Diabetes Care 29:2189-2195

33. Halford JC 2006 Obesity drugs in clinical development. Curr Opin Investig Drugs 7:312-318

34. Rushing PA, Hagan MM, Seeley RJ, Lutz TA, Woods SC 2000 Amylin: a novel action in the brain to reduce body weight. Endocrinology 141:850-853

35. Rushing PA, Hagan MM, Seeley RJ, Lutz TA, D'Alessio DA, Air EL, Woods SC 2001 Inhibition of central amylin signaling increases food intake and body adiposity in rats. Endocrinology 142:5035

36. Chapman I, Parker B, Doran S, Feinle-Bisset C, Wishart J, Strobel S, Wang Y, Burns C, Lush C, Weyer C, Horowitz M 2005 Effect of pramlintide on satiety and food intake in obese subjects and subjects with type 2 diabetes. Diabetologia 48:838-848

37. Chapman I, Parker B, Doran S, Feinle-Bisset C, Wishart J, Lush CW, Chen K, Lacerte C, Burns C, McKay R, Weyer C, Horowitz M 2007 Low-dose pramlintide reduced food intake and meal duration in healthy, normal-weight subjects. Obesity (Silver Spring) 15:1179-1186

38. Ceriello A, Piconi L, Quagliaro L, Wang Y, Schnabel CA, Ruggles JA, Gloster MA, Maggs DG, Weyer C 2005 Effects of pramlintide on postprandial glucose excursions and measures of oxidative stress in patients with type 1 diabetes. Diabetes Care 28:632-637

39. Ahren B 2003 Gut peptides and type 2 diabetes mellitus treatment. Curr Diab Rep 3:365-372

40. Dillon JS, Tanizawa Y, Wheeler MB, Leng XH, Ligon BB, Rabin DU, Yoo-Warren H, Permutt MA, Boyd AE 3rd 1993 Cloning and functional expression of the human glucagon-like peptide-1 (GLP-1) receptor. Endocrinology 133:1907-1910

41. Fehmann HC, Habener JF 1992 Insulinotropic hormone glucagon-like peptide-I(737) stimulation of proinsulin gene expression and proinsulin biosynthesis in insulinoma beta TC-1 cells. Endocrinology 130:159-166

42. Kieffer TJ, McIntosh CH, Pederson RA 1995 Degradation of glucose-dependent insulinotropic polypeptide and truncated glucagon-like peptide 1 in vitro and in vivo by dipeptidyl peptidase IV. Endocrinology 136:3585-3596
43. Imeryuz N, Yegen BC, Bozkurt A, Coskun T, Villanueva-Penacarrillo ML, Ulusoy NB 1997 Glucagon-like peptide-1 inhibits gastric emptying via vagal afferentmediated central mechanisms. Am J Physiol 273:G920-G927

44. Jeha GS, Heptulla RA 2006 Newer therapeutic options for children with diabetes mellitus: theoretical and practical considerations. Pediatr Diabetes 7:122-138

45. Deacon CF 2005 What do we know about the secretion and degradation of incretin hormones? Regul Pept 128:117-124

46. Lugari R, Dell'Anna C, Ugolotti D, Dei Cas A, Barilli AL, Zandomeneghi R, Marani B, Iotti M, Orlandini A, Gnudi A 2000 Effect of nutrient ingestion on glucagon-like peptide 1 (7-36 amide) secretion in human type 1 and type 2 diabetes. Horm Metab Res 32:424-428

47. Vilsboll T, Krarup T, Sonne J, Madsbad S, Volund A, Juul AG, Holst JJ 2003 Incretin secretion in relation to meal size and body weight in healthy subjects and people with type 1 and type 2 diabetes mellitus. J Clin Endocrinol Metab 88:27062713

48. Porksen S, Nielsen LB, Kaas A, Kocova M, Chiarelli F, Orskov C, Holst JJ, Ploug KB, Hougaard P, Hansen L, Mortensen HB 2007 Meal-stimulated glucagon release is associated with postprandial blood glucose level and does not interfere with glycemic control in children and adolescents with new-onset type 1 diabetes. J Clin Endocrinol Metab 92:2910-2916

49. Dupre J 2005 Glycaemic effects of incretins in Type 1 diabetes mellitus: a concise review, with emphasis on studies in humans. Regul Pept 128:149-157

50. Dupre J, Behme MT, Hramiak IM, McFarlane P, Williamson MP, Zabel P, McDonald TJ 1995 Glucagon-like peptide I reduces postprandial glycemic excursions in IDDM. Diabetes 44:626-630

51. Behme MT, Dupre J, McDonald TJ 2003 Glucagon-like peptide 1 improved glycemic control in type 1 diabetes. BMC Endocr Disord 3:3

52. Creutzfeldt WO, Kleine N, Willms B, Orskov C, Holst JJ, Nauck MA 1996 Glucagonostatic actions and reduction of fasting hyperglycemia by exogenous glucagon-like peptide I(7-36) amide in type I diabetic patients. Diabetes Care 19:580-586

53. Drucker DJ 2003 Glucagon-like peptides: regulators of cell proliferation, differentiation, and apoptosis. Mol Endocrinol 17:161-171

54. Abraham EJ, Leech CA, Lin JC, Zulewski H, Habener JF 2002 Insulinotropic hormone glucagon-like peptide-1 differentiation of human pancreatic islet-derived progenitor cells into insulin-producing cells. Endocrinology 143:3152-3161

55. Campbell SC, Macfarlane WM 2002 Regulation of the pdx1 gene promoter in pancreatic beta-cells. Biochem Biophys Res Commun 299:277-284

56. Li Y, Cao X, Li LX, Brubaker PL, Edlund H, Drucker DJ 2005 beta-Cell Pdx1 expression is essential for the glucoregulatory, proliferative, and cytoprotective actions of glucagon-like peptide-1. Diabetes 54:482-491

57. Chakrabarti SK, James JC, Mirmira RG 2002 Quantitative assessment of gene targeting in vitro and in vivo by the pancreatic transcription factor, Pdx 1 . Importance of chromatin structure in directing promoter binding. J Biol Chem 277:13286-13293

58. Tourrel C, Bailbe D, Meile MJ, Kergoat M, Portha B 2001 Glucagon-like peptide-1 and exendin- 4 stimulate beta-cell neogenesis in streptozotocin-treated newborn rats resulting in persistently improved glucose homeostasis at adult age. Diabetes 50:1562-1570

59. Xu G, Stoffers DA, Habener JF, Bonner-Weir S 1999 Exendin-4 stimulates both beta-cell replication and neogenesis, resulting in increased beta-cell mass and improved glucose tolerance in diabetic rats. Diabetes 48:2270-2276

60. Drucker DJ 2003 Glucagon-like peptide-1 and the islet beta-cell: augmentation of cell proliferation and inhibition of apoptosis. Endocrinology 144:5145-5148

61. Itoh A, Maki T 1996 Protection of nonobese diabetic mice from autoimmune diabetes by reduction of islet mass before insulitis. Proc Natl Acad Sci USA 93:11053-11056

62. Dupre J, Behme MT, McDonald TJ 2004 Exendin-4 normalized postcibal glycemic excursions in type 1 diabetes. J Clin Endocrinol Metab 89:3469-3473

63. Gutniak M, Orskov C, Holst JJ, Ahren B, Efendic S 1992 Antidiabetogenic effect of glucagon-like peptide-1 (7-36) amide in normal subjects and patients with diabetes mellitus. N Engl J Med 326:1316-1322

64. Triplitt C, Wright A, Chiquette E 2006 Incretin mimetics and dipeptidyl peptidase-IV inhibitors: potential new therapies for type 2 diabetes mellitus. Pharmacotherapy 26:360-374 